\title{
UKRAINE'S PLACE AND CHALLENGES IN THE EASTERN EUROPEAN PRODUCTION OF CHICKEN EGGS
}

\author{
Svetlana Tereschenko ${ }^{1}$, Elena Diachenko²
}

\begin{abstract}
Research subject. This report examines the current situation in poultry egg sector development in countries of Eastern Europe, features and challenges for Ukrainian eggs sector. The aim of the work is to summarize theoretical and practical aspects of improving the economic efficiency of poultry industry enterprises, to analyse the current state of the organization of egg poultry production, to develop and substantiate general recommendations for improving the state of the poultry industry at specialized enterprises. The methodology of the study includes statistical methods and methods of economic and comparative analysis, etc. The article presents the results of research on the dynamics of poultry development in Eastern Europe and Ukraine in particular. The movement of poultry, the level of poultry production and the production of chicken eggs, consumption of poultry products are analysed. The functional and organizational structure of the poultry business in Ukraine is developed. The general structure of poultry production allocation is provided, which proves the formation of poultry farming as an industrial business and reduction in the share of poultry keeping in households due to the concentration of production in specialized enterprises. The main producers of poultry products in Ukraine are revised. The dynamics of sales prices for chicken eggs and main factors influencing its annual fluctuations are investigated. The export potential of poultry farming is analysed, as well as the main importer countries of Ukrainian poultry production. The issue of modern challenges and problem areas of production of the corresponding products is investigated, concerning less manoeuvrability of small poultry farms, their inability to influence the conjuncture of the poultry market. The main threats to the activities of enterprises are named, first of all, by external factors: the economic situation in the country, which affects purchasing power of buyers, the level of egg prices, increased competition from large enterprises and enterprises of EU member states, livestock diseases and the epidemiological situation in the country. The analysis of the possibilities of further development of poultry farms, taking into account the existing potential and modern poultry business problems, is carried out. The main directions for improving production with the aim of improving the efficiency of the poultry industry are determined: improving biotechnological processes, providing a set of measures improving poultry, compliance stocking density of birds in the poultry house, proper nutrition by scientifically grounded norms of consumption of nutrients and elements; improvement of methodological basis of state supervision over the quality and safety of food products and raw materials; creation of modern instrumental analytical framework and quality control and safety of food raw materials and foodstuffs, etc.
\end{abstract}

Key words: poultry business, agribusiness, economic efficiency of poultry, poultry subcomplex, export of egg products.

JEL Classification: Q10, O13, L23, L66

\section{Introduction}

The chicken egg market is one of the foundations for the stable development of Eastern European economies. This is primarily due to the fact that eggs, as a food product, are one of the most important products, affordable, nutritious, and necessary. In addition, the particular location of the countries of Eastern Europe, especially Ukraine, their climatic features are favourable for the development of the industry.

Corresponding author:

${ }^{1}$ Sumy National Agrarian University, Ukraine.

E-mail: s.i.terechenko@gmail.com

${ }^{2}$ Sumy National Agrarian University, Ukraine.

E-mail: ekrynychnaya@yahoo.com
The current state of the economy of Ukraine and countries of Eastern Europe requires further careful study of improving the enterprise's efficiency. This includes requirements for improving and monitoring the quality of products, the introduction of modern control systems security products, intensification of production at saving resources, reducing energy consumption and overall cost reduction. It should be understood that all requirements need to be provided 
in conditions of not determined pricing policy and instability in the economy. Therefore, stability and even survival of the business depends on a balanced solution to minimize costs, improving product quality to EU norms and standards, increasing profitability.

Especially those issues related to businesses of the agroindustrial complex of Ukraine because Ukraine has very favourable climatic and geographical conditions for the development of agriculture and this is an industry that can remain the only stable and profitable, ensuring food security in an unstable geopolitical world situation.

Poultry - one of the areas of agriculture, which is developing rapidly, reaching the best indicators of development since the 90th XX AC, while significantly improving the material and technical conditions, production technology, and so on. In addition, poultry products, filling the domestic market with valuable and, importantly, affordable in price products and raw materials, has excellent opportunities to enter the world market, providing an increase in exports. Improving the efficiency of poultry in the current economic environment is an important issue in the development of agriculture.

Poultry in Eastern Europe is a traditional agriculture sector, stimulated by appropriate climatic conditions and developed grain farming. Poultry is the most quick and effective livestock industry. It provides a population with dietary food products (eggs, chickens meat, turkeys, ducks, etc.), which is relatively cheaper than other kinds of protein products and more accessible to the public. In addition, the poultry industry provides raw materials and has a number of advantages over other livestock sectors, higher weight gain per unit of feed, rapid growth, earliness, etc.

\section{Literature review}

The domestic and foreign practice has significant experience in solving problems of market poultry products. The transition of poultry industry to a market economy was a complex process and requires comprehensive research of market structure issues; study the interaction of economic actors and producers of poultry products market, a more sophisticated economic mechanism in the regional market of poultry products.

Problems of poultry industry development and food security in the vector of meat providing have been studied by leading scientists, such as V. Andreychuk, R. Buryak, E. Wexler, M. Demyanenko, T. Boyko, V. Mesel-Veselyak, Kirilenko, B. Miller, S. Mikhailov, V. Pryadko, Y. Riabokon, Y. Stavska, M. Shkliar, F. Yaroshenko, Conrad Caspari, Edward Oliver, John Nganga, Mariana Ricci, and many others. Works of these scientists consider the poultry industry in the forecast of its further development. But the poultry industry requires constant attention and analysis of trends influenced by globalization changes. There is much attention paid on the expansion of poultry production in the world. However, the promotion of the production consumer markets faces significant competition because it requires constant improvement of technology, processing of products, the introduction of modern quality standards, strategic planning, and so on. Therefore, the question of improving the efficiency of poultry production does not lose its relevance. There remains the need to analyse the current state, factors that positively and negatively affect the development of poultry farming. As the poultry provide the population with quality and dietary products and animal protein, its development is an important task. To date, poultry popularity ranks second after the pork. Experts say that by 2020 poultry takes the first place (Ukraine increased the import of poultry meat; FAO: World market of poultry).

\section{Analysis of the dynamics of the poultry industry}

Analysing the production of poultry in Eastern Europe, some preliminary conclusions can be drawn. First, there is a general tendency of increasing poultry production (Figure 1), including an increase in a number of chickens, increase and consolidation of companies engaged in the production of poultry products, including chicken and egg production.

Food demand for eggs increases from year to year all over the world. However, data indicate that the population of some countries of Eastern Europe has not yet reached the standards of rational consumption of protein products, including poultry - meat and eggs. In recent years, chicken meat and eggs consumption was up to $75 \%$ of the rational norms.

Poultry business - a part of a unified system of agribusiness, which is based on a unified organizational and economic mechanism of functioning, which is an integrated, open to socio-economic system, developed under the influence of external factors (market) and internal environment, which is mediated by conditions of agribusiness and includes a set of diversified businesses and organizations specifically involved in the production, harvesting, transportation, processing, storage, and final distribution of poultry (Afanasyev, Ploha, 2007). It is paid much attention to the development of poultry in Eastern Europe. These are the state programs of development of poultry farming, to stabilize and increase poultry production. A network of breeding poultry farms includes breeding and genetic centres with its subsidiaries, breeding poultry plants reproducers first order, second order reproducers, breeder, breeding herd, breeding farms and so on, which is the production base of poultry and fully meets the need in breeding products in the future. 


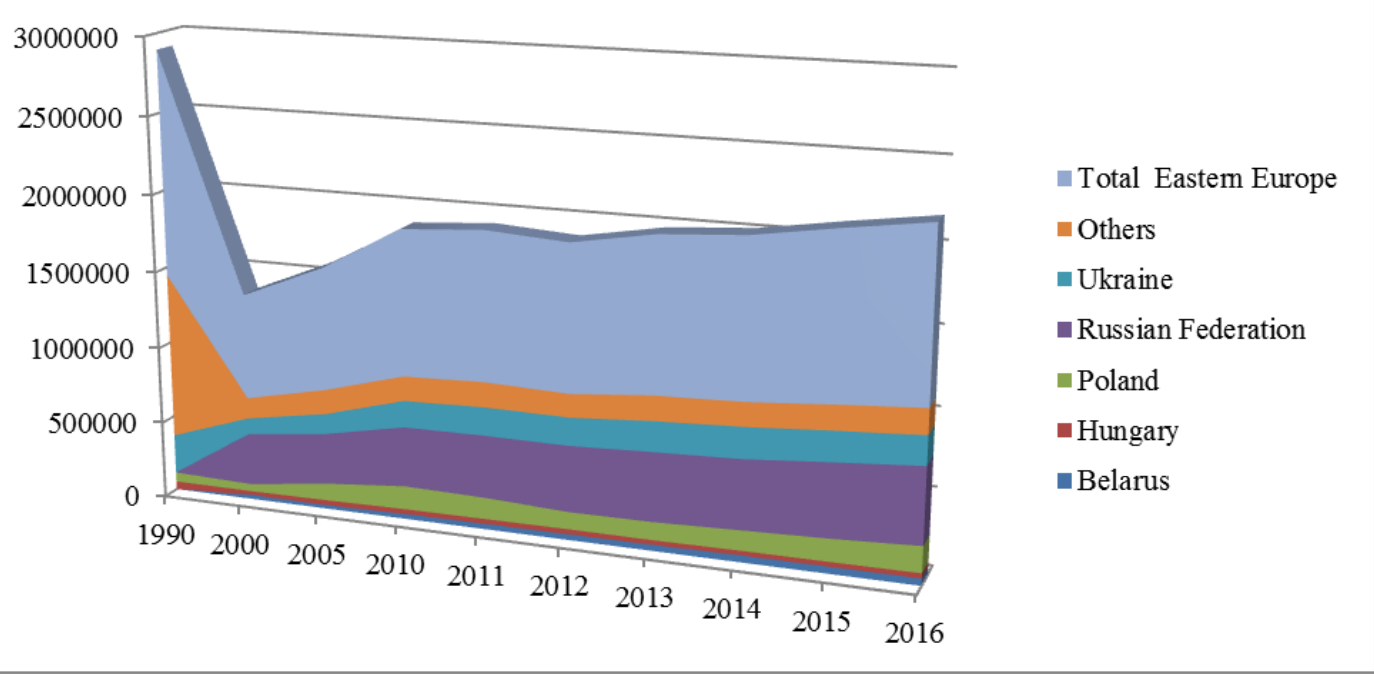

Figure 1. Development of poultry in Eastern Europe

Source: FAO STAT data base

EU countries produced 12,623.7 thousand tons of poultry meat or 450.8 thousand tons for one country. The leaders are France (13.6\%), the UK (12.8\%), Poland (12.2\%), Germany (11.3\%), Italy (10\%), Spain (9.2\%). Ukraine according to FAO is on the 26th place in the world in the production of poultry meat. The largest egg producer is China with up to $40 \%$ of global production, followed by the United States (7\%) and India (6\%).

Ukraine by 1991 was a part of a number of countries with high levels of the industry. In historical perspective, the development of the industry was characterized by a decline in production of poultry products from the $1990-1997 \mathrm{~s}$, and the revival of production in 1998 and to date (Zbarskiy, Babiyenko, Kulayets, Syniavska, Khomenko, 2013). Production of poultry meat reached $80 \%$ of the best indicator 1990 . The production of chicken eggs reached $95 \%$ of the 1990 figure.

Structure of poultry species composition is: keeping chicken meat and egg direction - 91\%; goose $-2.5 \%$; ducks $-5.3 \%$; turkeys - about $1 \%$, other birds (ostriches, quail, etc.) $-0.5 \%$ of the total poultry held on farms of all categories.

More than half of poultry products produced on specialized enterprises. It is quite logical and reasonable for poultry-the industry responds positively to the processes of specialization and concentration of production and reaches the highest level of efficiency. Therefore, in recent years, we can observe a tendency to increase the number of poultry farms, the figure almost reaches the level of 1991, when the development of poultry in Ukraine was the highest.

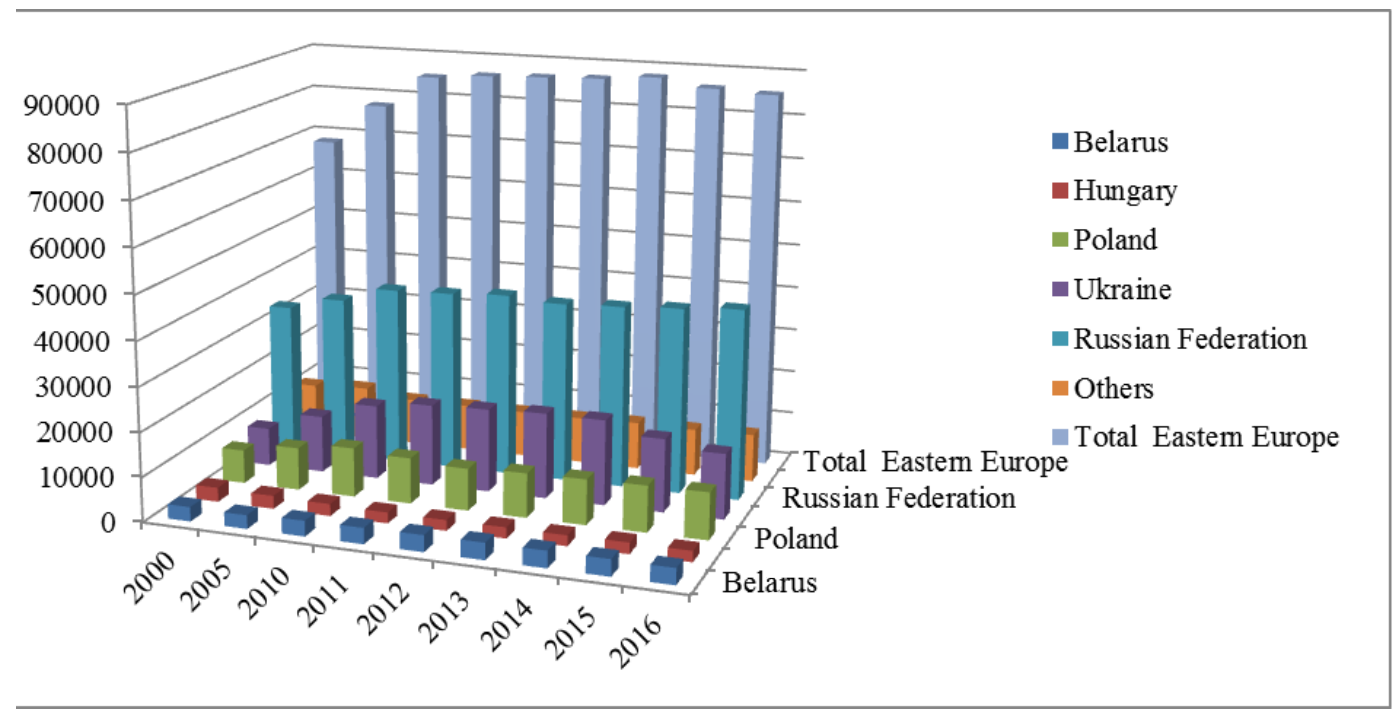

Figure 2. Dynamics of production of chicken eggs in Eastern Europe

Source: FAO STAT data base 


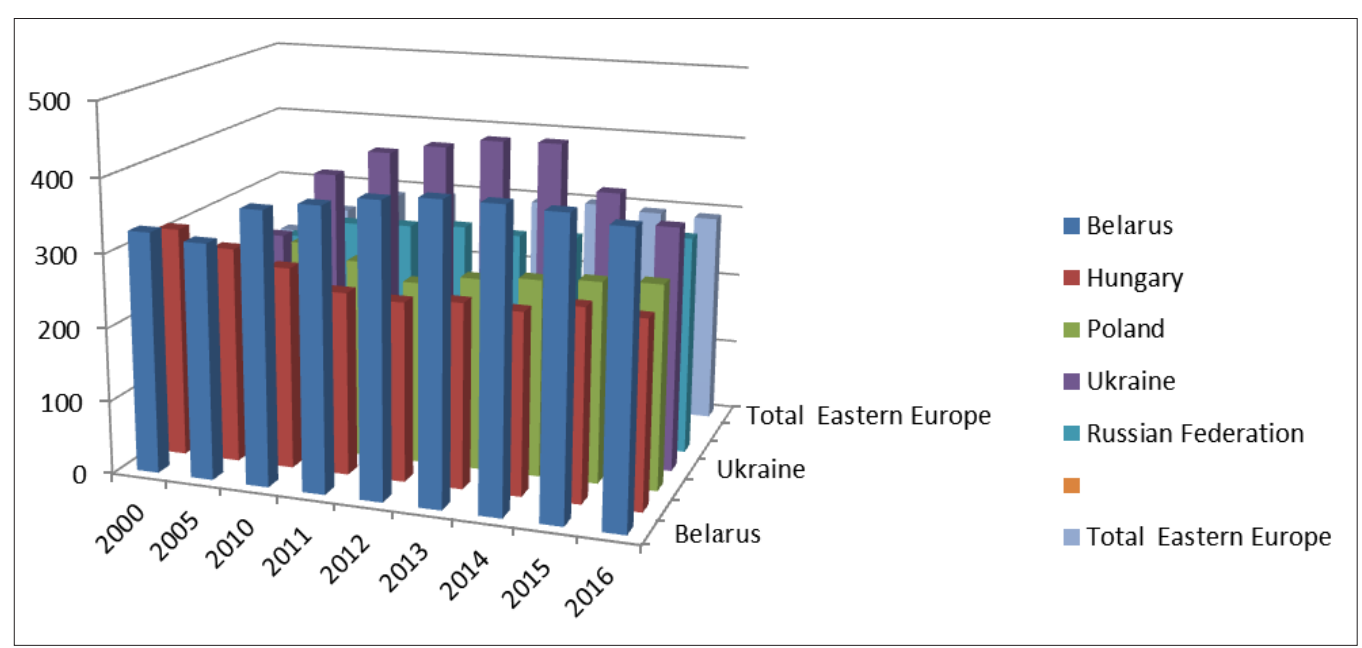

Figure 3. Production of chicken eggs per capita, pieces

Source: FAO STAT data base, own calculations

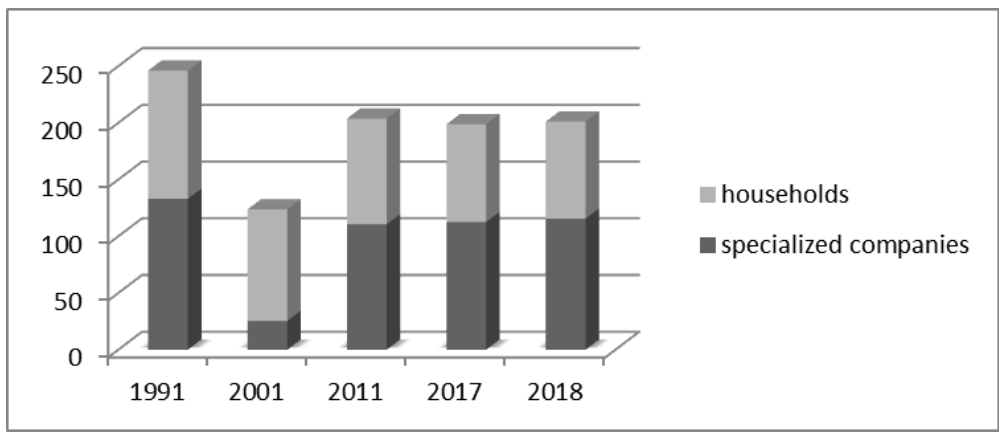

Figure 4. Structure of poultry allocation in Ukraine, thousand heads

Structural characteristics of poultry agribusiness are represented as a block diagram showing the functional and organizational structure of the poultry business (Figure 1). Now the association "Union of Poultry Breeders of Ukraine" represents the interests of the poultry industry. Founders are the 78 companies producing up to $83 \%$ of broiler meat and up to $78 \%$ of eggs in Ukraine. Association "Union of Poultry Breeders of Ukraine" was registered on June 4, 2003. The purpose of the association - participation in the development and implementation of programs and stabilization of poultry in Ukraine, raising the competitiveness of domestic producers of poultry products and other activities aimed at the development of the poultry industry.

The production link of the poultry business includes: breeding enterprises, suppliers of veterinary services (medicines, vaccines, care, etc.), suppliers of feed, and so on. Commodity poultry farms are divided into: poultry farms, poultry factories, integrated-farm enterprises, production associations.

In recent years, the situation of poultry production in Ukraine negatively affected by the following main factors: Ukraine's loss of some territories and the related military actions in the eastern part of the country, the downturn in some sectors of Ukrainian economy; decrease in purchasing power during the years of 2014-2016. Constraining factors for poultry industry comprise the rising production costs. Even with modern technologies of breeding animals and birds, it is difficult to achieve the desired economic effect. Thus, the poultry industry costs largely depend on feed costs (Kolos, 2014). Those, in turn, depend on the price of grain, protein, vitamin and mineral supplements. In the cost structure, the feed component takes up to $70 \%$. In addition, the total cost is affected by wage growth, significantly higher cost of energy, veterinary medicines, etc.

As it turned out, the following environmental factors as fluctuations of the national currency, fluctuating prices for imported goods have to suffice significant impact on the development of poultry in Ukraine. Today many production facilities, including the production of young, hatching eggs, veterinary medicines and other equipment tied to the price in the dollar, which means that the cost of poultry will grow, especially apply to the fact that medium and small poultry farms are not exporters. Those Ukrainian companies who receive foreign currency from exports don't have such serious risks. So we can predict that poultry producers of table 


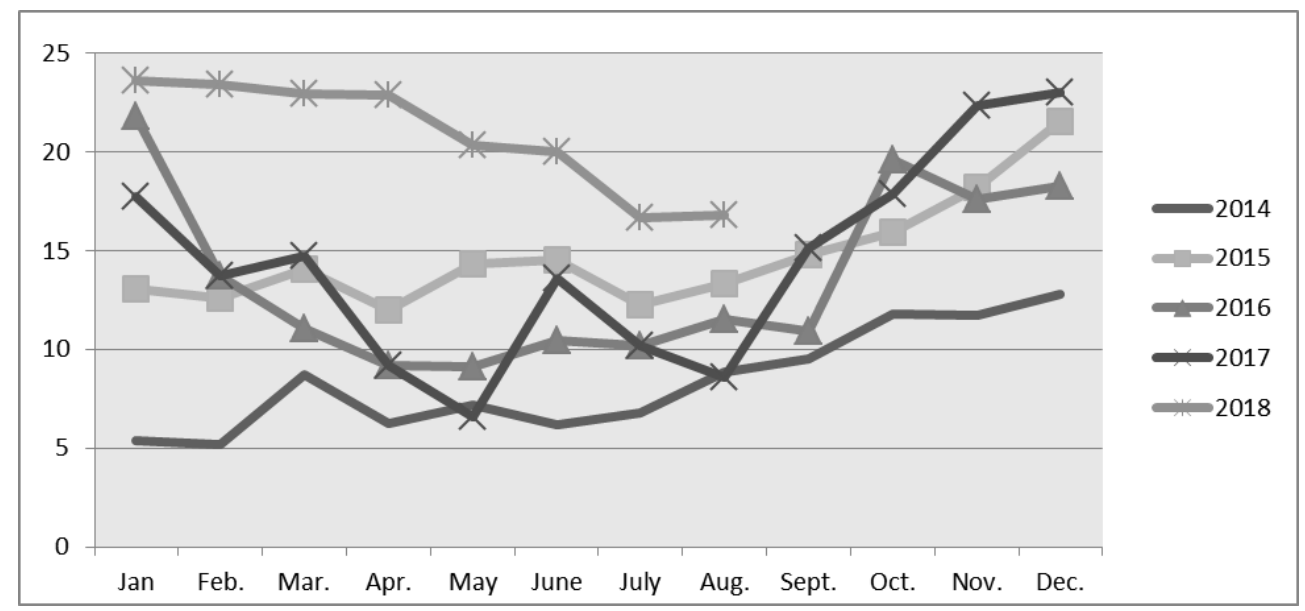

Figure 5. Dynamics of chicken eggs prices in Ukraine, UAH

eggs will have to pay the last money to purchase capital goods or work in a substantial way to reduce production costs (Kolos, 2014).

Political changes in Ukraine also affect the work of poultry enterprises. There is a break in ties with big Crimean reproducers, the search for new partners, which leads to an increase in the cost of hatching eggs and young birds.

An important factor in making a profit of chicken eggs production is the price of their sale. This is a rather difficult predicted value that may have fluctuations both toward the increase and aside to decrease over the year. The fluctuation in the selling price of an egg is affected by many factors: from macroeconomic factors such as the state of Ukrainian egg export to the pricing policy of giant companies (Avangard, Ovostar, etc.) which, due to greater concentration and integration of production, may have more opportunities to reduce their cost, and consequently, a decrease in the selling price during the peak periods of egg collection. Seasonal fluctuations in the price of chicken eggs also take place in the Ukrainian market (see Figure 5).

The largest producers of poultry meat in Ukraine are MHP, Complex Agromars, LLC "Poultry Complex 'Dniprovskiy”,' Corporation "Agro-Oven”, JSC "Vladimir-Volyn Poultry Farm". The largest producer of eggs: Avangardco IPL, Ovostar Ltd, GC "InterZaporozhye", Avias 2000 TOV, PF "Krupets", "Poultry Factory Podillya” LLC, Ternopilska Poultry Farm PJSC (Karpenko, 2015).

Among poultry exporting countries, Ukraine occupies 8th place in the world. Speaking about Ukraine's place among the countries-producers in Europe, we occupy the sixth position in the production of poultry, behind such countries as Poland, Germany, France, Britain, and Italy. In fact, the volume of exports to the EU for Ukraine is limited by the quota of 36 tons of poultry, but companies-producers constantly put this question to the Ministry of Agrarian Policy and Food of Ukraine in order to increase this quota to 100 tons. However, this question is not easy because it requires approval from all EU countries.

In recent years, it observed the tendency of reducing imports of poultry products. The main supplier of chicken meat to the Ukrainian market was Poland, which accounts for about half the volume of supply. Germany takes second place with a share of $28 \%$ in the structure of imports.

One of the import growth factors is the agreement on free trade zone between Ukraine and the EU. It made easier for Europe poultry producers to get to our market.

Meanwhile, there is a recent increase in the production of frozen poultry meat in Ukraine, which is mainly exported. This is circumstantial evidence of the attractiveness of production aimed at foreign markets for Ukrainian poultry producers.

The highest demand for Ukrainian poultry is in Iraq, Kazakhstan, and the Netherlands. The main importers of eggs were the UAE (by $\$ 8.19$ million), which bought 8.47 thousand tons of the product. Behind them is Iraq, which bought 5.38 thousand tons of eggs for $\$ 5.19$ million. Further - Qatar with 1.88 thousand tons of eggs for $\$ 1.81$ million.

In recent years, Ukraine has significantly increased exports of eggs. For five years, the UAE increased imports almost 20 times. According to the forecasts of scientists (FAO: World market of poultry), the volume of eggs export to this country in 2017 reached a record level, Ukraine plans to supply to the UAE more than 34 thousand tons of this product. The share of the UAE in the total egg exports in 2017 was $47.6 \%$. It is pleasant to note that in recent years, Ukraine develops eggs processing with subsequent export of the finished egg products, which is a very positive trend. Development of eggs export does not affect domestic consumption, because at present the production of eggs in Ukraine fully meets the needs of domestic consumers.

The main importing countries of fresh eggs from Ukraine were: Iraq (28,277.3 tons), the United Arab Emirates (19,178.5 tons), Moldova (2231.6 tons). 


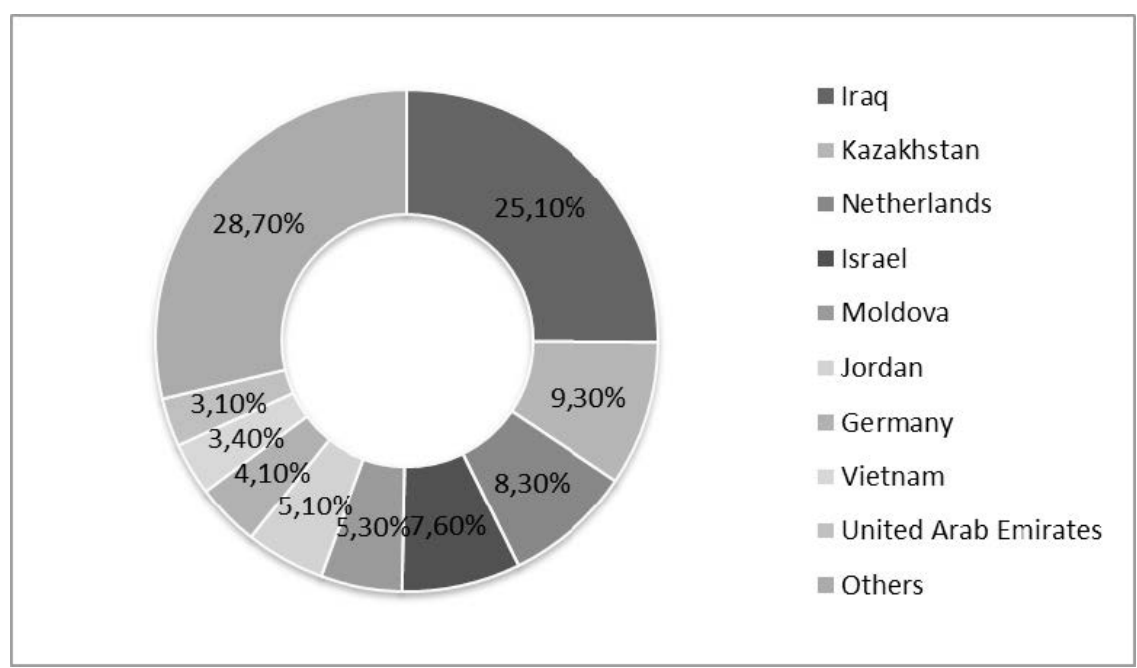

Figure 6. Main countries-importers of poultry from Ukraine

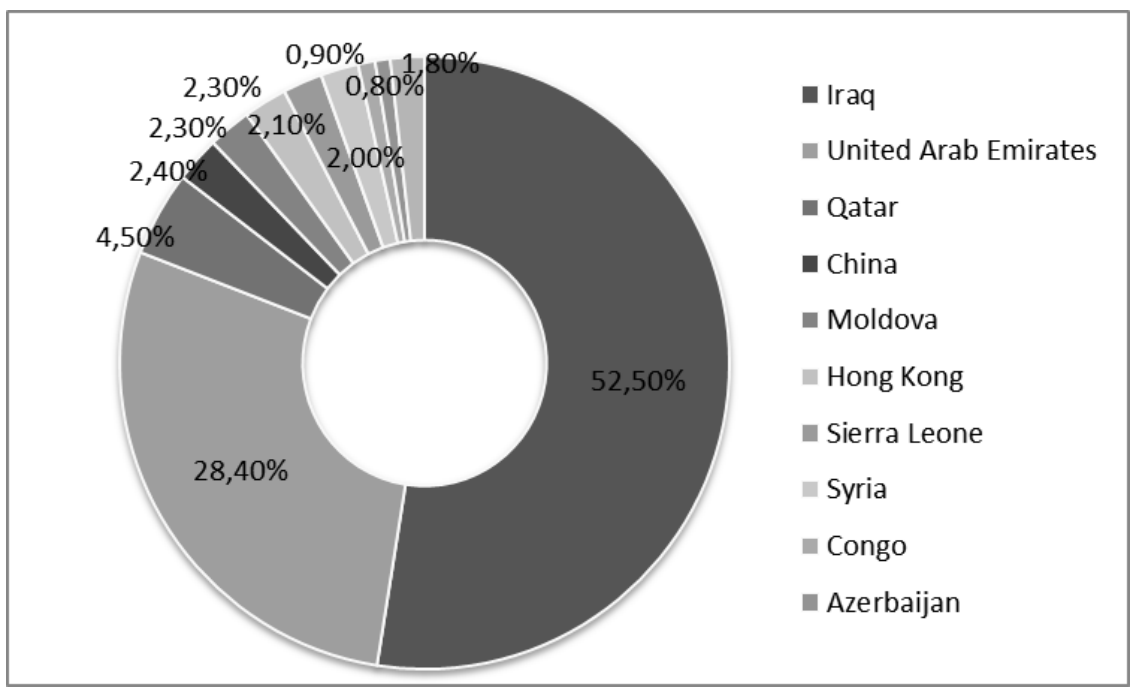

Figure 7. Main countries-importers of fresh bird eggs from Ukraine

The main countries-importers of egg and eggs products are the Middle East. Also, there is expanding the relationship in this regard with the countries of the African continent. Ukraine also received a quota for eggs export to the European Union.

\section{Suggestions and conclusions}

System evaluation of the results leads to the following proposals:

There is a need for further formation and development of regional poultry breeding and genetic complex adapted to the conditions and pace of modern innovative development of poultry business. Organization of an effective mechanism of renovation bird species composition should include organizational, legal, financial, and regulatory institutions of reproductive subcomplex.

To activate the process of formation of the integrated structures in agribusiness, due to the need to ensure technological, organizational, and economic cohesion and achieving continuous production, storage, processing, and sale of poultry products, it is necessary to solve the problems of institutional changes in the poultry business in terms of involvement of private households in the vertical integration processes (on the basis of contracts or agreements with industry).

The efficiency of this interaction is, on the one hand, the increasing commercialization of small forms of agribusiness through the provision of complete feed for all age-sex groups of birds, veterinary and zoo-technical maintenance and purchase of excess poultry. On the other hand, targeting industrial economies, including local processing industries to cheaper raw materials, reduce the costs and reduce risks in an unstable economic environment prevailing in the country.

To decrease and gradually eliminate the dependence of food security on poultry imports should resume implementation of the policy of moderate protectionism on domestic producers. In addition, there is a need to 
control the importation of breeding birds (parental forms and final hybrids) from abroad, to support the domestic poultry.

An analysis of the possibilities of a poultry enterprise to improve the production efficiency under conditions of an unstable economic system can be carried out, for example, by matrix methods (including SWOT analysis), mathematical, expert methods, etc.

The cellular equipment used in most poultry farms in Ukraine may become obsolete in the context of associate membership with EU countries, most of which have recently introduced the retention of poultry not in cages, but on the floor. These are specific requirements for the quality of finished products (eggs). Flooring requires much larger areas for poultry houses, other equipment, knowledge and practical skills of staff. The change of equipment is considered as having a future perspective.

But at the same time, there are some serious threats to the activities of enterprises. First of all, these are external factors: the economic situation in the country, which affects the purchasing power of buyers, the price of eggs, the rate of credit and the opportunity to get a loan. Inflation processes make production indeterminate in the context of profit gaining - currency fluctuations can provoke an unpredictable change in the cost of feed components for poultry, and hence the cost of egg production is significantly increasing.

The challenges for the company are also increased by competition from large enterprises and from the side of enterprises of EU member states. The threat lies in the fact that the cost of production in integrated associations can be objectively lower than in small poultry farms. Also, enterprises with large volumes of commodity products have better opportunities and access to supermarket chains and access to the world market.

A serious threat to the poultry farm is a livestock disease that can lead to the fall of the stock and even the death of the bird. Some infectious diseases include restrictions on the sale of poultry products. Quarantine restrictions may apply even to companies that do not have these diseases but are in the region of a tense epidemiological situation.

Thus, the main directions of improving production with the aim of improving the efficiency of poultry industry determines: improving biotechnological processes, providing a set of measures improving poultry, compliance stocking density of birds in the poultry house, proper nutrition by scientifically grounded norms of consumption of nutrients and elements; abidance to the basic microclimate parameters, ventilation, illumination indoors, timely disinfection, disease prevention; improving storage of poultry products throughout the movement of raw materials and products from poultry complex to the consumer; the use of poultry by-products to produce valuable fertilizer for livestock; ensuring maximum preservation of nutritional value and quality, adherence to storage conditions and terms of its implementation; improvement of methodological basis of state supervision over the quality and safety of food products and raw materials; creation of modern instrumental analytical framework and quality control and safety of food raw materials and foodstuffs; assistance of state and local government concerning innovation support in agriculture and poultry industry in particular, which requires flows of investment at the state level. A common situation is when the financial resources of the state budget aimed the innovation activities do not spend on modern innovative designs but provide baldly existence of current innovation infrastructure and is not able to build the innovative potential of poultry as one of the priority sectors of agribusiness.

Further development of poultry in Ukraine must come from global trends, as well as with established production capacity and accumulated experience of their own poultry.

\section{References:}

Afanasyev, M. V., Ploha, O. B. (2007). Ekonomika pidpryyemstva. Business Economics, Kharkiv: 320.

Karpenko, S. N. (2015). State of the industry and prospects of development of poultry in Ukraine. Report on the XI International Conference "Poultry - 2015". Truskavets. Foods and facts, 10(62), 6-7.

Kolos, N. (2014). From abilities - on request. Nashe ptakhivnytstvo, 3(33), 6-9.

Kolos, N. (2014). Under the sign of modernization. Nashe ptakhivnytstvo, 2(32), 6-8.

Zbarskiy, V. K., Babiyenko, M. F., Kulayets, M. M., Syniavska, I. M., Khomenko, M. P. (2013). Ekonomika silskoho hospodarstva: Navch. posib. Economy of Agriculture: Training Guidances.

News: chicken. Retrieved from: http://www.ukrinform.ua/ukr/news/tags/kuryatina?page=1

Ukraine increased the import of poultry meat. Retrieved from: http://www.ukragroconsult.com/news/ukrainauvelichila-import-myasa-птиці

FAO: World market of poultry. Retrieved from: http://www.fao.org 